\title{
PENINGKATAN KETERAMPILAN PROSES SAINS SISWA SEKOLAH DASAR MELALUI MODEL PEMBELAJARAN BERBASIS MASALAH
}

\author{
Yuyu Yuliati ${ }^{1}$ ) \\ yuyuliati74@gmail.com
}

\begin{abstract}
ABSTRAK
Penelitian ini didasarkan pada masih rendahnya kualitas pembelajaran di SD dalam mengimplementasikan pembelajaran yang dapat meningkatkan keterampilan proses sains. Berdasarkan alasan tersebut tujuan penelitian ini yaitu untuk mendeskripsikan apakah data peningkatan keterampilan proses sains siswa yang mendapatkan pembelajaran berbasis masalah (PBM) lebih baik dibandingkan siswa yang mendapatkan pembelajaran bukan PBM. Metode penelitian yang digunakan yaitu quasi eksperiment dengan desain pre-and post test design. Penelitian ini dilaksanakan di kelas V salah satu sekolah dasar negeri di Kabupaten Majalengka pada tahun ajaran 2014/2015 dengan subjek penelitian sebanyak 24 siswa kelas eksperimen dan 24 siswa kelas kontrol. Kelas ekperimen diberi perlakuan PBM, sedangkan kelas kontrol dengan bukan PBM. Kedua kelompok diberikan pre test dan post test dengan menggunakan instrumen tes yang sama. Instrumen yang digunakan terdiri atas butir soal pilihan ganda untuk mengukur keterampilan proses sains, dan lembar observasi untuk melihat keterlaksanaan pembelajaran. Data pre test dan post test diolah menggunakan bantuan program SPSS 20 for Windows. Hasil analisis data menunjukan bahwa keterampilan proses sains pada kelas eksperimen baik secara keseluruhan maupun pada setiap indikatornya mengalami peningkatan yang lebih baik dibanding siswa kelas kontrol. Adapun peningkatan secara keseluruhan untuk keterampilan proses sains yaitu sebesar 0,56 berada pada kategori sedang. Sehingga dapat disimpulkan bahwa peningkatan keterampilan proses siswa yang mendapatkan pembelajaran berbasis masalah (PBM) lebih baik dibandingkan siswa yang mendapatkan pembelajaran bukan PBM.
\end{abstract}

Kata Kunci: Keterampilan proses sains, Pembelajaran berbasis masalah (PBM), dan bukan PBM.

\footnotetext{
${ }^{1}$ Penulis adalah dosen tetap Prodi PGSD Fakultas Pendidikan Dasar dan Menengah Universitas Majalengka
} 


\section{PENDAHULUAN}

Ilmu Pengetahuan Alam (IPA) adalah salah satu muatan yang harus dikembangkan dalam kurikulum KTSP. Harapan dalam KTSP untuk mata pelajaran IPA adalah siswa dapat mengembangkan pengetahuan dan pemahaman konsepkonsep IPA yang bermanfaat dan dapat diterapkan dalam kehidupan sehari-hari. Pada hakikatnya IPA berhubungan dengan cara mencari tahu tentang alam secara sistematis sehingga IPA bukan hanya penguasaan kumpulan pengetahuan berupa fakta, konsep, prinsip saja tetapi juga merupakan suatu proses penemuan. Relevan dengan tujuan pendidikan nasional, Rustaman (2007:97) menjelaskan bahwa pendidikan sains memiliki visi untuk mempersiapkan siswa yang melek sains dan teknologi. Harapan dari siswa yang melek sains dan teknologi yaitu mampu memahami diri dan lingkungan sekitarnya melalui pengembangan keterampilan proses, sikap ilmiah, keterampilan berpikir, penguasaan konsep sains, kegiatan teknologi, dan upaya pengelolaan lingkungan secara bijaksana yang dapat menumbuhkan sikap pengagungan terhadap Tuhan Yang Maha Esa.

Keberhasilan pendidikan sains dalam mewujudkan visinya ditunjukkan apabila siswa memahami apa yang dipelajari serta dapat mengaplikasikannya dalam kehidupan sehari-hari. Bertemali dengan itu maka proses pembelajaran IPA selayaknya dikondisikan untuk mengembangkan kemampuan berpikir, memecahkan masalah dan menekankan pada pemberian pengalaman langsung melalui kegiatan inkuiri ilmiah (scientific inquiry) dengan tujuan dapat membantu siswa memperoleh pemahaman yang lebih mendalam tentang alam sekitar. Selanjutnya dalam kurikulum sains sekolah dasar, Bundu (206:49) menekankan bahwa pembelajaran sains sebaiknya memuat tiga komponen, yaitu:

Pertama, pengajaran sains harus merangsang tumbuhnya intelektual dan perkembangan siswa. kedua, pengajaran sains harus melibatkan siswa dalam kegiatan-kegiatan praktikum/percobaan tentang hakikat sains. Ketiga, sains pada sekolah dasar seharusnya: (a) mendorong dan merangsang terbentuknya sikap ilmiah, (b) mengembangkan kemampuan penggunaan keterampilan proses sains, (c) menguasai pola dasar pengetahuan sains, dan (d) merangsang tumbuhnya sikap berpikir kritis dan rasional.

Dari uraian di atas jelas bahwa pembelajaran IPA pada jenjang sekolah dasar menekankan pada pemberian pengalaman belajar secara langsung melalui penggunaan dan pengembangan keterampilan proses dan sikap ilmiah.

Keterampilan proses sains (KPS) penting dimiliki oleh siswa dalam kegiatan inkuiri ilmiah guna menyelesaikan berbagai masalah sains. Keterampilan proses sains adalah semua kemampuan yang diperlukan untuk memperoleh, mengembangkan, dan menerapkan konsep-konsep, prinsip-prinsip, hukum-hukum dan teori-teori sains baik berupa kemampuan mental, fisik, maupun kemampuan sosial. Menurut Rustaman (2005:80) keterampilan proses sains meliputi kegiatan melakukan pengamatan, menafsirkan pengamatan, mengklasifikasi, berkomunikasi, memprediksi, merumuskan hipotesis, menganalisis data, merancang eksperimen atau percobaan, menerapkan konsep atau prinsip, mengajukan pertanyaan, menggunakan alat, melakukan pengukuran dan penarikan kesimpulan.

Faktanya yang terjadi di lapangan pembelajaran sains masih terbilang belum menyentuh pengembangan keterampilan proses sains secara optimal. Penelitian Suastra (dalam Aziz, 2012: 4) menjelaskan bahwa rendahnya pembelajaran sains disebabkan karena tolak ukur keberhasilan pendidikan di sekolah masih difokuskan pada segi konsep. Pembelajaran sains selama ini memiliki kecenderungan hanya 
mengasah aspek mengingat (remembering) dan memahami (understanding), kurang melatih keterampilan siswa dalam berinkuiri. Keadaan ini diperparah dengan kondisi dimana fokus penyajian pembelajaran hanya dilakukan dengan kegiatan ceramah sehingga mengakibatkan kegiatan siswa ketika belajar sangat terbatas. Penjelasan tersebut didukung oleh hasil penelitian Pusat Kurikulum Departemen Pendidikan Nasional tahun 2007 (dalam Handika, I \& Wangid, M. N., 2013) yang menyatakan bahwa metode ceramah dengan cara menulis di papan tulis merupakan metode yang paling banyak digunakan. Berbagai temuan tersebut juga didukung oleh hasil studi pendahuluan yang dilakukan peneliti di salah satu sekolah dasar di kabupaten Majalengka, bahwa pertanyan-pertanyaan yang dilontarkan guru pada pelaksanaan pembelajaran sains masih didominasi oleh aspek ingatan, selain itu kegiatan pembelajaran yang dilakukan di kelas juga belum dapat mengoptimalkan siswa secara aktif memecahkan masalah dan melakukan inkuiri. Pada pelaksanaannya siswa lebih banyak diam mendengarkan penjelasan guru serta mencatat hal-hal yang penting.

Rendahnya keterampilan proses sains (KPS) pada akhirnya bermuara pada rendahnya hasil belajar sains siswa. Hasil survey TIMSS (Trends in International Mathematics and Science Study) yang mengukur kemampuan scientific inquiry, menunjukan bahwa rata-rata skor prestasi sains siswa Indonesia pada tahun 1999 yaitu 435 sehingga menjadikan Indonesia berada pada urutan 32 dari 39, pada tahun 2003 berada pada urutan 37 dari 46 dengan rata-rata skor 420, begitupun hasil pada tahun 2007 berada pada urutan 35 dari 49 dengan skor rata-rata 427, dan hasil survey 2011 juga menunjukan hasil yang relatif sama yaitu berada pada urutan 39 dari 41 dengan skor rata-rata 406 sedangkan ratarata skor internasional sudah mencapai skor 500. Berdasarkan hasil interpretasi survey
TIMSS terhadap kemampuan siswa Indonesia ditinjau dari aspek kognitif (knowing, applying, reasoning), ternyata secara rata-rata masih berada pada kemampuan knowing (http://timssandpirls.bc.edu/data-release2011/pdf/Overview-TIMSS-and-PIRLS2011-Achievement.pdf).

Berdasarkan data empiris yang telah dikemukakan di atas, perlu dilakukan sebuah perubahan besar dan mendasar dalam pelaksanaan pembelajaran sains. Berbagai upaya seyogyanya dilakukan memiliki tujuan untuk membenahi pembelajaran yang bermuara pada peningkatan mutu proses dan hasil pembelajaran sehingga pada akhirnya dapat mempersiapkan siswa di masa depan.

Salah satu alternatif model pembelajaran yang memberikan peluang bagi siswa untuk memiliki keterampilan berpikir kreatif dan mengembangkan keterampilan proses sains adalah model pembelajaran berbasis masalah (PBM). Arends (2008:41) menyatakan bahwa model pembelajaran berdasarkan masalah merupakan suatu pendekatan pembelajaran dimana siswa mengerjakan permasalahan yang autentik dengan maksud untuk menyusun pengetahuan mereka sendiri, mengembangkan inkuiri, keterampilan berpikir tingkat tinggi, kemandirian, dan percaya diri.

Keberhasilan model pembelajaran berbasis masalah dapat terlihat dari keberhasilan model ini menyelesaikan berbagai permasalahan pembelajaran yang tertuang dalam beberapa penelitian. Penelitian Novita, L.D, dkk (2014) mengenai pembelajaran berbasis masalah terhadap keterampilan proses, menunjukan hasil bahwa terdapat perbedaan yang signifikan pada keterampilan proses sains antara kelompok siswa yang dibelajarkan menggunakan model pembelajaran Problem Based Learning (PBL) dan kelompok siswa yang dibelajarkan menggunakan model pembelajaran konvensional pada siswa kelas V SD di Gugus IV Diponegoro 
Kecamatan Mendoyo tahun ajaran 2013/2014. Berdasarkan beberapa penelitian di atas jelas bahwa model pembelajaran berbasis masalah dapat meningkatkan keterampilan proses sains siswa, namun data hasil penelitian menunjukan bahwa peningkatan yang didapat hanya berada pada kriteria sedang. Dengan demikian peneliti menganggap perlu melakukan penelitian mengenai peningkatan keterampilan proses sains siswa melalui model pembelajaran berbasis masalah pada pembelajaran IPA.

\section{LANDASAN TEORI}

1. Keterampilan Proses Sains

Menurut Rustaman

(2005:78)

keterampilan proses sains adalah semua kemampuan yang diperlukan untuk memperoleh, mengembangkan, dan menerapkan konsep-konsep, prinsip-prinsip, hukum-hukum dan teori-teori sains baik berupa kemampuan mental, kemampuan fisik, maupun kemampuan sosial. Pada penelitian ini keterampilan proses sains yang akan diukur mengingat subjek penelitian merupakan siswa kelas V SD dengan rentang usia 10-11 tahun yaitu pada perkembangan kognitif tahap peralihan dari operasi konkret ke operasi formal sesuai dengan pernyataan Bundu (2006:49) sudah mampu menguasai 10 keterampilan proses sains.

Sehingga pada penelitian ini jenis keterampilan proses sains yang akan diukur meliputi keterampilan (a) mengamati dengan indikator mengumpulkan fakta yang relevan; (b) mengelompokan dengan indikator mencari dasar pengelompokan; (c) menginterpretasi/menafsirkan dengan indikator menemukan pola atau keteraturan pengamatan; (d) meramalkan dengan indikator mengemukakan sesuatu yang terjadi pada keadaan yang mungkin teramati; (e) bertanya dengan indikator mengajukan pertanyaan terkait dengan percobaan; (f) mengajukan hipotesis dengan indikator dapat membuat hipotesis; (g) merencanakan percobaan dengan indikator menentukan alat, bahan, atau sumber yang akan digunakan dan menentukan langkah kerja; (h) menerapkan konsep dengan indikator menggunakan konsep pada pengalaman baru untuk menjelaskan apa yang sedang terjadi; (i) berkomunikasi dengan indikator mengubah penyajian data hasil pengamatan pada bentuk grafik; dan (j) menyimpulkan dengan indikator menarik kesimpulkan berdasarkan hasil interpretasi terhadap data dan menarik kesimpulan data hasil percobaan.

2. Model Pembelajaran Berbasis Masalah

Arends (2008:41), model pembelajaran berdasarkan masalah merupakan suatu pendekatan pembelajaran dimana siswa mengerjakan permasalahan yang autentik dengan maksud untuk menyusun pengetahuan mereka sendiri, mengembangkan inkuiri, keterampilan berpikir tingkat lebih tinggi, mengembangkan kemandirian, dan percaya diri.

Karakteristik model pembelajaran berbasis masalah menurut Tan (2004:9) yaitu:

a. the problem is the starting point of learning.

b. the problem is usually a real-world problem that appears unstructured. if it is a simulated problem, it should be as authentic as possible.

c. the problem calls for multiple perspectives. the use of crossdisciplinary knowledge is a key feature in many pbl curricula. in any case, pbl encourages the solution of the problem by making use of knowledge from various subjects and topic.

$d$. the problem challenges students' current knowledge, attitudes, and competencies, thus calling for identification of learning needs and new areas of learning.

e. self-directed learning is primary. thus, students assume major responsibility 
for the acquisition of information and knowledge.

$f$. harnessing of a variety of knowledge sources and the use and evaluation of information resources are essential pbl processes.

g. learning is collaborative, communicative, and cooperative. students work in small groups with a high level of interaction for peer learning, peer teaching, and group presentations.

$h$. development of inquiry and problemsolving skills is as important as content knowledge acquisition for the solution of the problem. the pbl tutor thus facilitates and coaches through questioning and cognitive coaching.

$i$. closure in the pbl process includes synthesis and integration of learning.

j. PBL also concludes with an evaluation and review of the learner's experience and the learning process.

Dari penjelasan tersebut jelas bahwa Pada pembelajaran berbasis masalah, masalah digunakan sebagai stimulus dan fokus bagi aktivitas belajar siswa. Masalah yang dijadikan sebagai stimulus digunakan untuk mengaktifkan keingin tahuan siswa sebelum mulai mempelajari suatu subjek. Permasalahan yang dimunculkan dalam pembelajaran biasanya berupa kasus yang berkaitan dengan disiplin ilmu yang dipelajari. Masalah yang dijadikan sebagai fokus pembelajaran dapat diselesaikan siswa melalui kerja kelompok. Melalui berbagai kegiatan tersebut diharapkan dapat memberikan pengalaman belajar yang beragam diantaranya pengalaman belajar yang berhubungan dengan pemecahan masalah dan kerjasama dalam kelompok.

Arends (2008:57) mengemukakan bahwa pembelajaran berbasis masalah dilaksanakan dengan lima langkah (fase) kegiatan. Adapun tahapan pembelajaran atau sintaks pembelajaran berbasis masalah adalah sebagai berikut: memberikan orientasi tentang permasalahan pada siswa, mengorganisasikan siswa untuk meneliti, membantu investigasi mandiri dan kelompok, mengembangkan dan mempresentasikan artefak dan exhibit, dan menganalisis dan mengevaluasi proses mengatasi masalah.

Terdapat beberapa keunggulan dari pembelajaran berbasis masalah diantaranya, yaitu: model pembelajaran berbasis masalah dapat mendorong siswa membentuk pola pikir, mampu memecahkan masalah, memiliki pengetahuan mengenai konten masalah dunia nyata, meningkatkan dan mengembangkan motivasi belajar yang dapat bermuara terhadap peningkatan hasil belajar siswa. Model pembelajaran berbasis masalah juga lebih menekankan pada pola student center learning. Selain itu, yang terpenting adalah menciptakan suasana pembelajaran secara bermakna sehigga dapat memunculkan rasa percaya diri siswa dan mengoptimalkan segala macam kemampuan yang dimiliki siswa.

Namun dari segala kelebihan, model PBM juga memiliki kendala yang harus dijadikan sebagai pertimbangan oleh guru diantaranya, yaitu: (1) bila siswa tidak memiliki minat atau mempunyai kepercayaan bahwa masalah dapat dipecahkan, maka akan merasa enggan untuk mencoba; (2) tanpa pemahaman mengapa mereka berusaha untuk memecahkan masalah, maka siswa tidak akan belajar; dan (3) keberhasilan pembelajaran berbasis masalah membutuhkan cukup waktu untuk persiapan.

\section{METODOLOGI}

Penelitian ini menggunakan pendekatan kuantitatif. Sedangkan metode penelitian yang digunakan yaitu quasi eksperimental. Desain yang digunakan dalam penelitian ini adalah pre- and post test design (Creswell, 2008:314). Penelitian ini dilakukan dengan maksud untuk menguji suatu ide atau perilaku atau prosedur untuk mengetahui pengaruhnya terhadap outcome dengan 
mengubah suatu kondisi dan pengamati pengaruhnya terhadap hal lain. Dalam desain penelitian ini terdapat dua kelas yaitu select control group dan select experimental group (Creswell, 2008:314). Kelas ekperimen diberi perlakuan berupa pembelajaran berbasis masalah (PBM), sedangkan kelas kontrol menggunakan bukan PBM yaitu pembelajaran yang biasa sehari-hari dilakukan oleh siswa. Kedua kelas diberikan pre test dan post test dengan menggunakan instrument test yang sama. Hasil tes dari kedua kelas tersebut dianalisis dan dideskripsikan untuk melihat sejauh mana peningkatan keterampilan berpikir kreatif dan keterampilan proses sains siswa melalui PBM. Deskripsi desain penelitian ini dapat dilihat pada Gambar 1. berikut.

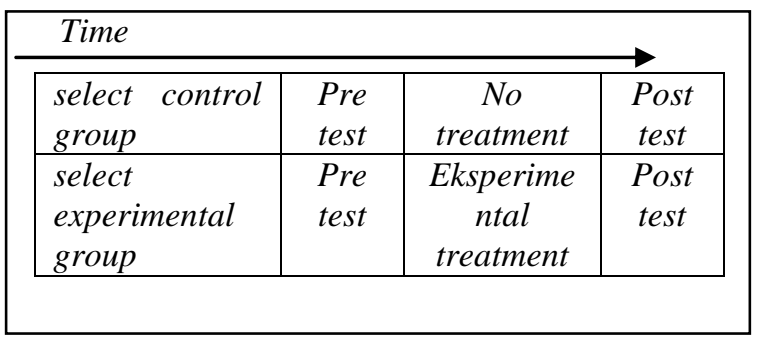

Gambar 1 Quasi-Exsperiment pre-and post test design (Creswell, 2008:314)

Penelitian ini dilaksanakan di salah satu sekolah dasar negeri di Kabupaten Majalengka. Alasan pemilihan sekolah tersebut sebagai tempat penelitian yaitu dikarenakan secara umum memiliki fasilitas sekolah yang cukup memadai, kualitas guru yang relatif sama, dan akses yang cukup mudah untuk peneliti dalam melakukan penelitian. Adapun kegiatan penelitian dilaksanalkan pada rentang waktu dari tanggal 16 Maret s/d 4 Mei 2015. Partisipan penelitian ini yaitu siswa kelas $\mathrm{V}$ di salah satu sekolah dasar negeri di Kabupaten Majalengka pada tahun ajaran 2014/2015. Jumlah partisipan pada penelitian ini yaitu 48 orang yang terbagi kedalam dua kelas yaitu kelas VA dan VB. Pemilihan siswa kelas VA dan VB sebagai partisipan penelitian didasarkan pada pertimbangan hasil belajar siswa yang relatif seimbang dilihat dari perolehan nilai rata-rata kelas.

Penentuan sampel pada penelitian ini dilakukan secara purposive sampling yaitu pengambilan subjek berdasarkan tujuan atau disesuaikan dengan tujuan penelitian (Sukmadinata, 2010:254). Pada penelitian ini, kelas VA ditentukan sebagai kelas eksperimen dengan jumlah siswa sebanyak 24 orang siswa. Sedangkan kelas VB ditentukan sebagai kelas kontrol dengan jumlah siswa sebanyak 24 orang siswa.

Kegiatan pengumpulan data dilakukan pada setiap kegiatan siswa dan situasi yang berkaitan dengan penelitian. Untuk mendapatkan data yang diharapkan dalam penelitian ini peneliti melakukan pengumpulan data melalui teknik tes dan observasi. Dalam penelitian ini tes yang diberikan berupa tes keterampilan proses sains yang merupakan tes tertulis. Tes tersebut diberikan sebelum dan sesudah proses pembelajaran IPA. Kegiatan observasi dilakukan dilakukan di kelas eksperimen untuk melihat keberlangsungan model pembelajaran berbasis masalah dalam upaya peningkatan keterampilan proses sains. Adapun instrumen yang digunakan untuk memperoleh data dalam penelitian ini terdiri atas:

\section{Butir soal}

Soal pilihan ganda digunakan untuk mengukur keterampilan proses sains siswa. Soal pilihan ganda berjumlah 18 butir soal dengan 4 alternatif pilihan. Setiap soal dibuat sesuai dengan indikator masingmasing keterampilan.

2. Lembar observasi kegiatan siswa dan guru

Selama pembelajaran berlangsung dilakukan observasi terhadap aktivitas yang dilakukan guru dan siswa pada setiap pertemuan untuk melihat keterlaksanaan PBM. Kegiatan observasi ini bertujuan untuk mengetahui perkembangan siswa, aktivitas, kinerja, partisipasi, keterampilan siswa dan guru selama pembelajaran. Lembar observasi berisi daftar isian yang 
menggambarkan aktivitas guru dan siswa pada tahapan-tahapan pembelajaran berbasis masalah (PBM).

Data hasil observasi dan tes siswa kemudian dianalisis. Data hasil observasi terhadap aktivitas siswa dan guru selama proses pembelajaran dianalisis secara deskriptif. Sedangkan data hasil tes keterampilan proses siswa dianalisis secara kuantitatif dengan menggunakan statistic package for social science (SPSS) 20 for windows. Data yang akan diuji adalah data pre test, post test, dan $N$-gain keterampilan keterampilan proses sains. Pengujian $\mathrm{N}$-gain dilakukan untuk mengetahui peningkatan yang terjadi setelah diberikan tindakan, apakah peningkatan keterampilan keterampilan proses sains kelas eksperimen lebih baik dari kelas kontrol. Pengujian dua rata-rata dalam penelitian ini menggunakan uji $\mathrm{t}$ dengan taraf signifikansi $\alpha=0,05$. Adapun hipotesis penelitian pada penelitian ini adalah Peningkatan keterampilan proses sains siswa yang mendapatkan pembelajaran berbasis masalah (PBM) lebih baik dari pada siswa yang mendapatkan pembelajaran bukan PBM.

$\mathrm{H}_{0}: \mu_{1}=\mu_{2}:$ Tidak terdapat perbedaan peningkatan keterampilan proses sains antara siswa kelas eksperimen dan kelas kontrol

$\mathrm{H}_{1}: \mu_{1}>\mu_{2}$ : Peningkatan keterampilan proses sains siswa kelas eksperimen kebih baik dari kelas control

\section{HASIL DAN PEMBAHASAN}

Untuk melihat apakah terdapat perbedaan peningkatan keterampilan proses sains pada kelas eksperimen dan kelas kontrol maka data pre test dan post test diolah sehingga didapat skor $\mathrm{N}$-gain. Hasil pengolahan data pre test dan post test keterampilan proses sains menjadi $\mathrm{N}$-gain pada kelas eksperimen dan kelas kontrol dapat dilihat pada Tabel 1.
Tabel 1. Data peningkatan keterampilan proses sains siswa kelas eksperimen dan kelas kontrol

\begin{tabular}{|l|l|c|c|}
\hline \multirow{2}{*}{} & \multirow{2}{*}{ Kriteria } & \multicolumn{2}{|c|}{ Kelas } \\
\cline { 3 - 4 } & & $\begin{array}{c}\text { Eksperimen } \\
\mathrm{N}=24\end{array}$ & $\begin{array}{c}\text { Kontrol } \\
\mathrm{N}=24\end{array}$ \\
\hline \multirow{2}{*}{$\begin{array}{l}\text { Peningkatan } \\
(N \text {-gain })\end{array}$} & Tinggi & 9 orang & - \\
\cline { 2 - 4 } & Sedang & 11 orang & 9 orang \\
\cline { 2 - 4 } & Rendah & 4 orang & 15 orang \\
\hline
\end{tabular}

Berdasarkan tabel di atas, $\mathrm{N}$-gain semua siswa pada kelas eksperimen yang berjumlah 24 orang siswa mengalami peningkatan dengan kriteria yang bervariasi mulai dari rendah, sedang, sampai tinggi. Pada kelas eksperimen kriteria peningkatan mayoritas berada pada kriteria sedang. Sedangkan pada kelas kontrol dari 24 orang siswa mayoritas mengalami peningkatan hanya pada kriteria rendah.

Berikut adalah data perbandingan ratarata skor pre test, post test, dan $N$-gain keterampilan proses sains siswa kelas eksperimen dan kelas kontrol pada grafik berikut.

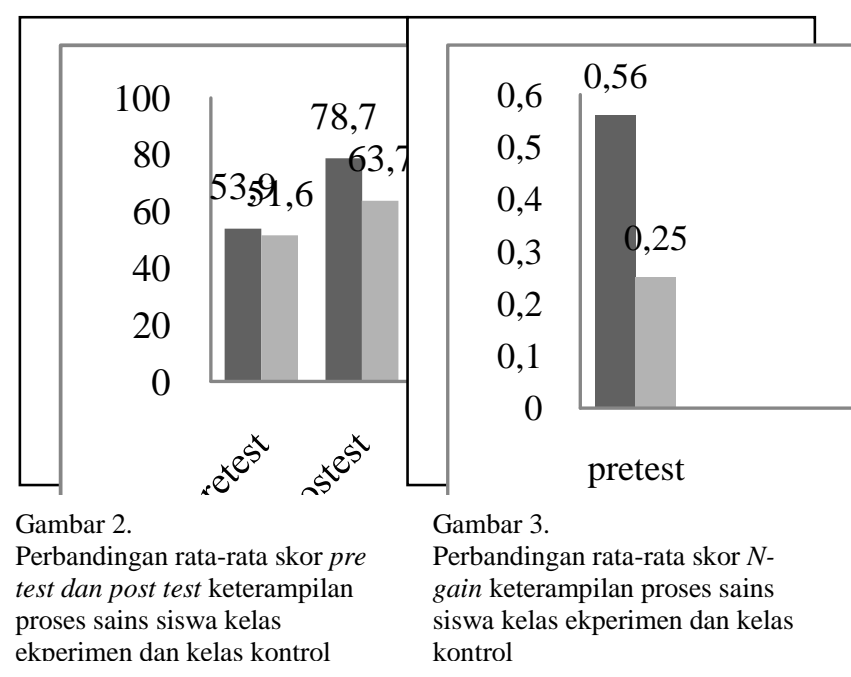

siswa kelas eksperimen dan siswa kelas kontrol tidak jauh berbeda. Hal ini menunjukan bahwa kemampuan awal keterampilan proses sains siswa sebelum perlakuan pembelajaran hampir merata. Setelah adanya pemberian berlakuan pembelajaran berbasis masalah (PBM) pada kelas eksperimen dan pembelajaran bukan PBM pada kelas kontrol, nilai post test baik pada kelas eksperimen maupun kelas kontrol penunjukan perbedaan secara 
kuantitas. Mutu peningkatan juga ditunjukan dengan $\mathrm{N}$-gain kedua kelas yang berbeda dapat dilihat pada Gambar 3. Ngain pada kelas eksperimen mencapai 0,56 dengan kriteria tinggi sedangkan pada kelas kontrol $N$-gain hanya mencapai 0,25 dengan kriteria rendah. Berdasarkan rata-rata skor post test dan $N$-gain tersebut secara kuantitas peningkatan keterampilan berpikir kreatif siswa kelas eksperimen lebih tinggi dari kelas kontrol.

Selanjutnya untuk mengetahui ada tidaknya perbedaan peningkatan keterampilan proses sains siswa antara kelas eksperimen yang mendapatkan pembelajaran berbasis masalah (PBM) dan siswa kelas kontrol yang mendapatkan pembelajaran bukan PBM, perlu dilakukan pengujian perbedaan dua rata-rata skor $N$ gain. Analisis data dilakukan menggunakan uji t jika rerata $N$-gain memenuhi syarat normalitas dan homogenitas, berbantuan software SPSS 20 dengan taraf signifikansi $\alpha=0,05$. Hasil pengolahan data yang menggambarkan peningkatan keterampilan proses sains secara lengkap dapat dilihat pada Tabel 2.

Tabel 2.

Rekapitulasi data hasil uji normalitas, uji homogenitas dan uji $t$ terhadap pre test, post test, dan $\mathrm{N}$-gain keterampilan proses sains

\begin{tabular}{|c|c|c|c|c|c|c|c|}
\hline \multirow{2}{*}{\multicolumn{2}{|c|}{ Uji }} & \multicolumn{2}{|c|}{ Pre test } & \multicolumn{2}{|c|}{ Post test } & \multicolumn{2}{|c|}{$N$-gain } \\
\hline & & Eksperimen & Kontrol & Eksperimen & kontrol & Eksperimen & kontrol \\
\hline \multirow{2}{*}{$\begin{array}{l}\text { Normalitas } \\
\mathrm{N}=24\end{array}$} & Sig & 0,112 & 0,273 & 0,51 & 0,446 & 0,605 & 0,734 \\
\hline & kesimpulan & Data normal & $\begin{array}{c}\text { Data } \\
\text { normal }\end{array}$ & Data normal & $\begin{array}{c}\text { Data } \\
\text { normal }\end{array}$ & Data normal & $\begin{array}{c}\text { Data } \\
\text { normal }\end{array}$ \\
\hline \multirow{2}{*}{$\begin{array}{l}\text { Homogenit } \\
\text { as } \\
\mathrm{N}=24\end{array}$} & Sig & \multicolumn{2}{|c|}{0,229} & \multicolumn{2}{|c|}{0,550} & \multicolumn{2}{|c|}{0,178} \\
\hline & kesimpulan & \multicolumn{2}{|c|}{ Data homogen } & \multicolumn{2}{|c|}{ Data homogen } & \multicolumn{2}{|c|}{ Data homogen } \\
\hline \multirow[t]{3}{*}{ Uji t } & $\begin{array}{l}\text { Sig } \\
(2 \text { tailed })\end{array}$ & \multicolumn{2}{|c|}{0,501} & \multicolumn{2}{|c|}{0,000} & \multicolumn{2}{|l|}{0,000} \\
\hline & $\begin{array}{l}\text { Sig } \\
(1 \text { tailed })\end{array}$ & \multicolumn{2}{|c|}{0,250} & \multicolumn{2}{|c|}{0,000} & \multicolumn{2}{|l|}{0,000} \\
\hline & kesimpulan & \multicolumn{2}{|c|}{$\begin{array}{ll}\text { Tidak } & \text { terdapat } \\
\text { perbedaan } & \\
\end{array}$} & \multicolumn{2}{|c|}{ Terdapat perbedaan } & \multicolumn{2}{|c|}{$\begin{array}{l}\text { Terdapat perbedaan } \\
\text { yang signifikan }\end{array}$} \\
\hline
\end{tabular}

Berdasarkan Tabel 2., hasil uji normalitas dan uji homogenitas data pre test, post test, dan $N$-gain pada kedua kelas berdistribusi normal dan memiliki varians homogen, dengan demikian asumsi statistik untuk melakukan uji perbedaan dua rata-rata secara parametrik telah terpenuhi. Adapun hasil uji t untuk data pre test menunjukan Sig $(2$ tailed $)=0,501>0,05$ artinya rataan skor pre test keterampilan proses sains sebelum perlakuan tidak memiliki perbedaan secara signifikan. Sedangkan hasil uji t untuk data post test menunjukan Sig $(1$ tailed $)=0,000<0,05$ artinya rataan skor post test keterampilan proses sains yang mendapatkan pembelajaran berbasis masalah (PBM) berbeda dengan siswa yang mendapatkan pembelajaran bukan PBM.
Selanjutnya, untuk membuktikan bahwa peningkatan keterampilan proses sains siswa kelas eksperimen lebih baik dari pada kelas kontrol dilakukan uji perbedaan dua rata-rata pada skor $N$-gain. Adapun hipotesis penelitian yang diajukan pada penelitian ini, yaitu: "Peningkatan keterampilan proses sains siswa yang mendapatkan pembelajaran berbasis masalah (PBM) lebih baik dari pada siswa yang mendapatkan pembelajaran bukan PBM". Untuk menguji hipotesis penelitian tersebut, dirumuskan hipotesis statistik berikut:

$\mathrm{H}_{0}: \mu_{1}=\mu_{2}$ : Tidak terdapat perbedaan peningkatan keterampilan proses sains antara siswa kelas eksperimen dan kelas kontrol 
$\mathrm{H}_{1}: \mu_{1}>\mu_{2}:$ Peningkatan keterampilan proses sains siswa kelas eksperimen kebih baik dari siswa kelas kontrol

Dengan menggunakan taraf signifikansi 0,05, maka kriteria pengambilan keputusannya adalah sebagai berikut:

Jika nilai signifikansi lebih kecil dari 0,05, maka $\mathrm{H}_{0}$ ditolak.

Jika nilai signifikansi lebih besar atau sama dengan 0,05 , maka $\mathrm{H}_{0}$ diterima.

Nilai Sig. (1-tailed) $N$-gain diperoleh dari $\frac{1}{2}$ Sig. (2-tailed) yaitu $0,000<0,05$, akibatnya $\mathrm{H}_{0}$ ditolak. Hal ini menunjukkan bahwa peningkatan keterampilan proses sains siswa kelas eksperimen lebih baik daripada siswa kelas kontrol. Berdasarkan penjelasan tersebut maka hipotesis penelitian dapat diterima.

Berdasarkan hasil analisis terhadap berbagai temuan hasil penelitian di atas, menunjukan bahwa peningkatan keterampilan proses sains siswa kelas $\mathrm{V}$ yang mendapatkan pembelajaran berbasis masalah (PBM) lebih baik dari pada siswa yang mendapatkan pembelajaran bukan PBM. Adapun kriteria peningkatan keterampilan proses sains berada pada kriteria sedang.

Pada penelitian ini juga dilakukan analisis pada tiap indikator keterampilan proses sains. Peningkatan tiap indikator KPS ditunjukan pada tabel 3.

Tabel 3.

Rekapitulasi skor pre tes, post test, dan $N$-gain tiap indikator keterampilan proses sains kelas eksperimen dan kelas kontrol

\begin{tabular}{|c|c|c|c|c|c|c|c|c|c|}
\hline \multirow{2}{*}{$\begin{array}{l}\text { No } \\
\text { Soal }\end{array}$} & \multirow{2}{*}{$\begin{array}{c}\text { Indikator } \\
\text { Keterampilan } \\
\text { Proses Sains }\end{array}$} & \multicolumn{4}{|c|}{ Kel Eksperimen } & \multicolumn{4}{|c|}{ Kel Kontrol } \\
\hline & & $\begin{array}{l}\text { Pre } \\
\text { tes }\end{array}$ & $\begin{array}{l}\text { Pos } \\
\text { tes }\end{array}$ & $\begin{array}{l}N- \\
\text { gain }\end{array}$ & Kriteria & $\begin{array}{l}\text { Pre } \\
\text { tes }\end{array}$ & $\begin{array}{l}\text { Pos } \\
\text { tes }\end{array}$ & $N$-gain & Kriteria \\
\hline 1,2 & pengamatan & 13,5 & 21,5 & 0,76 & tinggi & 14 & 17,5 & 0,35 & sedang \\
\hline $\begin{array}{l}16, \\
17\end{array}$ & klasifikasi & 17,5 & 21,5 & 0,62 & sedang & 11,5 & 13,5 & 0,16 & rendah \\
\hline 3,12 & bertanya & 13 & 18 & 0,45 & sedang & 11 & 14 & 0,23 & rendah \\
\hline 7,18 & prediksi & 9,5 & 13,5 & 0,28 & rendah & 11,5 & 13 & 0,12 & rendah \\
\hline 4,13 & hipotesis & 15,5 & 20 & 0,53 & sedang & 15,5 & 17 & 0,18 & rendah \\
\hline $\begin{array}{l}10, \\
11\end{array}$ & $\begin{array}{l}\text { merencanakan } \\
\text { percobaan }\end{array}$ & 4 & 21 & 0,85 & tinggi & 10,5 & 18 & 0,56 & sedang \\
\hline 5 & interpretasi & 15 & 19 & 0,44 & sedang & 15 & 12 & $-0,33$ & rendah \\
\hline 8,14 & $\begin{array}{l}\text { berkomu- } \\
\text { nikasi }\end{array}$ & 12 & 19 & 0,58 & sedang & 9 & 16,5 & 0,5 & sedang \\
\hline 6,9 & $\begin{array}{l}\text { menyim- } \\
\text { pulkan }\end{array}$ & 16 & 16,5 & 0,19 & rendah & 13,5 & 15,5 & 0,06 & rendah \\
\hline 15 & $\begin{array}{l}\text { menerapkan } \\
\text { konsep }\end{array}$ & 16 & 19 & 0,38 & sedang & 15 & 13 & $-0,22$ & rendah \\
\hline
\end{tabular}


Pada Tabel 3. terlihat bahwa skor rata-rata pre test pada setiap indikator keterampilan proses sains siswa tidak jauh berbeda antara siswa kelas eksperimen dan siswa kelas kontrol. Hal ini menunjukan bahwa kemampuan siswa pada tiap indikator keterampilan proses sains sebelum dilakukan perlakuan hampir merata. Setelah dilakukan perlakuan, perbedaan cukup jelas terlihat dari rata-rata skor post test untuk masingmasing kelas, kelas eksperimen yang menggunakan pembelajaran berbasis masalah (PBM) memiliki skor rata-rata lebih tinggi jika dibandingkan dengan kelas kontrol yang menggunakan model bukan PBM. Perbandingan juga terlihat dari rata-rata skor $N$-gain.

Berdasarkan Tabel 3. terdapat perbedaan skor $N$-gain tiap indikator keterampilan proses sains antara kelas eksperimen dan kontrol. Setiap indikator keterampilan proses sains pada kelas eksperimen seluruhnya mengalami peningkatan. Sedangkan pada kelas kontrol tidak semua indikator keterampilan proses sains mengalami peningkatan. Indikator yang tidak mengalami peningkatan yaitu interpretasi dan menerapkan konsep. Indikator keterampilan proses sains pada kelas eksperimen yang mengalami peningkatan tertinggi yaitu indikator keterampilan merencanakan percobaan dengan skor $\mathrm{N}$ gain 0,85 kemudian pada urutan ke dua yaitu indikator pengamatan dengan skor $N$-gain 0,76 dengan kriteria tinggi. Sedangkan peningkatan dengan kriteria rendah tampak pada indikator keterampilan prediksi dan menyimpulkan dengan masing-masing skor $\mathrm{N}$-gain 0,28 dan 0,19. Pada kelas kontrol indikator keterampilan proses sains masing-masing hanya mengalami peningkatan dengan kriteria rendah dan hanya indikator keterampilan pengamatan, merencanakan percobaan, dan berkomunikasi saja yang mendapatkan kriteria $\mathrm{N}$-gain sedang. Berdasarkan data tersebut secara kuantitas diketahui bahwa peningkatan tiap indikator keterampilan proses sains kelas eksperimen lebih baik daripada siswa kelas kontrol.

Peningkatan keterampilan proses sains siswa yang mendapatkan pembelajaran berbasis masalah (PBM) lebih baik dari pada siswa yang mendapatkan bukan PBM disebabkan oleh beberapa faktor. Pertama, model pembelajaran berbasis masalah (PBM) lebih menitik beratkan pada permasalahan-permasalahan autentik yang sering terjadi di lingkungan siswa. Siswa didorong untuk mengkonstruksi pengetahuannya sendiri dalam upaya memecahkan permasalahanpermasalahan tersebut. Pada pembelajaran berbasis masalah (PBM) guru sebagai fasilitator memiliki peranan untuk meningkatkan motivasi siswa ketika pengkonstruksi pengetahuannya secara mandiri. Berdasarkan hasil observasi ditemukan bahwa aktivitas dan interaksi siswa pada kelas eksperimen yang menggunakan pembelajaran berbasis masalah (PBM) berkembang lebih baik dibandingkan dengan kelas kontrol yang menggunakan bukan PBM. Pada penerapan pembelajaran berbasis masalah (PBM) peranan guru semakin berkurang pada setiap tahapannya. Hal ini dikarenakan guru pada model pembelajaran berbasis masalah (PBM) diposisikan sebagai fasilitator ketika siswa berupaya memecahkan permasalahan. Ke dua, langkah-langkah model pembelajaran berbasis masalah (PBM) mengharuskan siswa melakukan berbagai metode ilmiah yang di dalamnya terdapat keterampilan proses sains. Berbeda dengan pembelajaran bukan PBM yang dilaksanakan di kelas kontrol yang mana pada pelaksanaannya hanya sebatas dilakukan melalui kegiatan membaca, tanya jawab, kerja kelompok, dan guru memberikan penjelasan materi kemudian dilanjutkan dengan memberikan tugas. Langkah 
pembelajaran seperti ini mengakibatkan aktivitas siswa cukup terbatas.

Dengan demikian, peningkatan keterampilan proses sains siswa tidak terlepas dari aktivitas belajar yang dilakukan oleh siswa itu sendiri. Pada pelaksanaan pembelajaran berbasis masalah, aktivitas belajar siswa dimulai ketika guru mengorientasikan siswa pada permasalahan. Siswa mengamati dan memanfaatkan berbagai sumber untuk menentukan strategi dalam memecahkan masalah. Kemudian siswa menyajikan pengetahuan yang diperoleh bersama kelompoknya dan dievaluasi bersama.

Pada pengimplementasian model pembelajaran berbasis masalah (PBM) ini, teori konstruktivisme merupakan landasan utamanya. Hal ini dikarenakan siswa harus mengkonstruksi pengetahuannya sendiri secara aktif supaya siswa dapat menggali ide-ide dalam menemukan konsep dan memecahkan masalah. Pandangan konstruktivisme yang melandasi pembelajaran berbasis masalah (PBM) ini didasarkan pada teori Piaget, Vygotsky, dan Bruner. Pandangan Piaget menyatakan bahwa siswa dalam segala usia terlibat dalam segala proses pemerolehan informasi dan membangun pengetahuan mereka sendiri (Arends:47). Selanjutnya Vygotsky percaya bahwa interaksi sosial dengan orang lain memacu siswa pengkonstruksian ide-ide baru dan meningkatkan perkembangan intelektualnya.

Jika ditinjau dari langkah pembelajaran berbasis masalah (PBM), langkah yang pertama yaitu orientasi masalah. Pada tahap ini siswa belajar tentang bagaimana permasalahan tersebut terjadi dan apa yang menyebabkan permasalahan tersebut dapat terjadi. Dengan kata lain, siswa melakukan pengamatan/observasi sebagai langkah awal dalam melaksanakan pembelajaran. Keterampilan observasi dapat menjadi titik tumpu untuk pengembangan keterampilan proses sains berikutnya. Bundu (2006: 25) menyatakan bahwa "kemampuan melakukan observasi merupakan keterampilan yang paling mendasar dalam sains, dan penting untuk mengembangkan keterampilan proses yang lainnya".

Langkah yang ke dua, yaitu mengorganisir siswa untuk meneliti. Pada tahap ini siswa mencari informasi dari berbagai sumber yang terkait dengan permasalahan. Harapan dilaksanakannya kegiatan ini siswa mampu mengembangkan aspek keterampilan proses sains seperti merumuskan hipotesis berdasarkan informasi dan konsep yang telah dimiliki. Perumusan hipotesis mendorong siswa untuk mampu merancang kerja ilmiah. Selain itu pada tahap ini siswa juga dapat mengembangkan berbagai keterampilan proses sains lain seperti keterampilan mengamati, bertanya, merencanakan dan melaksanakan percobaan, dan berkomunikasi.

Langkah pembelajaran yang ke tiga, yaitu melakukan penyelidikan mandiri maupun kelompok. Langkah ini sangat erat kaitannya dengan aspek keterampilan proses sains, yakni merencanakan dan melaksanakan percobaan. Kegiatan yang dapat dilakukan siswa pada tahap ini adalah merencanakan sebuah penyelidikan untuk membuktikan hipotesis yang telah dirumuskan sebelumnya dengan bantuan teori dan konsep yang telah dimilikinya. Penerapan model pembelajaran berbasis masalah (PBM) mendorong siswa untuk menemukan sendiri jawaban atas permasalahan yang diberikan. Hal ini menunjukan bahwa dalam penerapan model pembelajaran berbasis masalah (PBM) melibatkan konsep belajar penemuan yang dikemukakan oleh Bruner. Ketika siswa didorong untuk melakukan kegiatan penyelidikan siswa dapat termotivasi dan meningkatkan kemampuan intelektualnya. Pendapat 
tersebut didukung oleh pernyataan Samatowa (2006:46) yang menyatakan bahwa "pembelajaran melalui discovery learning (penemuan) dapat meningkatkan motivasi belajar IPA siswa".

Langkah ke empat, yaitu mengembangkan dan menyajikan hasil penelitian. Pada tahapan pembelajaran ini aspek keterampilan proses sains yang dapat dikembangkan yaitu keterampilan interpretasi data dan berkomunikasi. Siswa dituntut aktif mencari solusi dari permasalahan yang diberikan berdasarkan data hasil penyelidikan yang telah dilakukan. Setelah diperoleh hasil dan solusi dari permasalahan tersebut, siswa perlu menyajikan kesimpulan yang diperoleh baik dalam bentuk laporan tertulis maupun lisan. Hal tersebut dimaksudkan agar siswa terbiasa melakukan analisis dan mengkomunikasikan hasil. Pada penelitian ini hambatan yang terjadi pada tahap ini yaitu alokasi waktu untuk melakukan kegiatan presentasi kurang memadai. Waktu cukup tersita pada kegiatan penyelidikan dan diskusi sehingga alokasi waktu untuk kegiatan presentasi menjadi kurang lama, namun alokasi waktu yang tersisa cukup untuk lima kelompok mempresentasikan hasil temuannya.

Langkah yang ke lima yaitu menganalisis dan mengevaluasi proses pemecahan masalah. Setelah mendapatkan masukan dan saran perbaikan baik dari guru maupun kelompok lain, siswa kemudian menyimpulkan solusi pemecahan masalah yang paling tepat untuk digunakan. Pada tahap ini keterampilan proses sains yang dikembangkan diantaranya yaitu keterampilan berkomunikasi dan menerapkan konsep.

Berdasar pada penjelasan di atas, terdapat beberapa temuan penting dalam penelitian ini yaitu (1) meskipun peningkatan keterampilan proses sains siswa yang mendapatkan pembelajaran berbasis masalah (PBM) lebih baik daripada keterampilan proses sains siswa yang mendapatkan bukan PBM, namun secara statistik peningkatan keterampilan proses sains yang dicapai masih berada pada kriteria sedang. Hal tersebut dikarenakan siswa belum terbiasa belajar dengan menggunakan pembelajaran berbasis masalah. Selama ini proses pembelajaran di kelas jarang sekali melibatkan siswa terlibat aktif mengembangkan metode ilmiah dalam kegiatan penyelidikan secara langsung. Kebiasaan belajar yang belum biasa melibatkan siswa secara aktif tersebut menyebabkan keterampilan proses sains siswa belum benar-benar terasah dengan baik. Faktor lain yang juga mempengaruhi adalah motivasi setiap siswa yang berbeda-beda, peningkatan setiap indikator keterampilan proses sains lebih baik dibandingkan dengan kelas kontrol terbukti dengan skor $N$-gain tiap indikator kelas eksperimen lebih tinggi dibandingkan dengan skor $\mathrm{N}$ gain kelas kontrol, (3) kemampuan prediksi masih kurang dipahami secara benar oleh siswa, (4) pada kelas eksperimen walaupun terjadi peningkatan pada indikator menyimpulkan, namun peningkatannya masih pada kriteria rendah, dan (5) kemampuan siswa dalam menganalisis data masih belum optimal karena siswa belum secara optimal menggunakan teori, prinsip, maupun persamaan yang relevan untuk menganalisis permasalahan, selain itu siswa juga masih belum optimal dalam mencari keterkaitan teori, prinsip, maupun persamaan yang ada sehingga kegiatan analisis masih belum dilakukan secara mendalam.

\section{SIMPULAN DAN SARAN}

A. Simpulan

Peningkatan keterampilan proses sains siswa yang mendapatkan pembelajaran berbasis masalah (PBM) lebih baik dari pada siswa yang 
mendapatkan pembelajaran bukan PBM. Peningkatan keterampilan proses sains siswa melalui pembelajaran berbasis masalah (PBM) berada pada kriteria sedang dengan $N$-gain 0,56 , sedangkan keterampilan proses sains siswa melalui pembelajaran bukan PBM berada pada kriteria rendah dengan $N$-gain 0,25 .

B. Saran

Meskipun dengan penerapan pembelajaran berbasis masalah (PBM) dapat meningkatkan keterampilan proses sains pada kriteria sedang, perlu adanya penelitian lebih lanjut pada materi dan subjek yang berbeda di tingkat sekolah dasar sebagai upaya untuk mengembangkan keterampilan proses sains siswa.

\section{DAFTAR PUSTAKA}

Arends. (2008). Learning to Teach. Yogyakarta: Pustaka Belajar.

Azis, S. (2012). Peningkatan Keterampilan Proses Sains dan Keterampilan Berpikir kreatif Melalui Pembelajaran Berbasis Projek. Tesis Program Studi Pendidikan Dasar. Bandung: SPS UPI (tidak diterbitkan).

Bundu, P. (2006). Penilaian Keterampilan Proses dan Sikap Ilmiah Dalam Pembelajaran Sains $S D$. Jakarta: Direktorat Jenderal Pendidikan Tinggi.

Creswell, J. (2008). Educational Research: Planning, Conducting, and Evaluating Quantitative and Qualitative Research, 3rd Edition.New Jersey: Person Education Inc.

Harlen, W. (1992). The teaching of science. London: David Fulton Publisher.

Handika, I \& Wangid, M. N., (2013). Pengaruh Pembelajaran Berbasis Masalah Terhadap Penguasaan Konsep Dan Keterampilan Proses Sains Siswa Kelas V. Jurnal Prima Edukasia, 1(1), hlm. 85-93.
Novita, L.D, Sudana, N.D, \& Riastini, N.P. (2014). Pengaruh Model Pembelajaran PBL Terhadap Keterampilan Proses Sains Siswa Kelas V SD di gugus IV Diponegoro Kecamatan Mendoyo. Jurnal Mimbar PGSD Universitas Pendidikan Ganesha Jurusan PGSD, 2 (1), hlm. 1-5.

Rustaman, N. et al. (2005). Strategi Belajar Mengajar Biologi. Malang: Universitas Negeri Malang.

Rustaman, N. (2007). Assesmen dalam Pembelajaran Sains. Bandung: Program doktor pendidikan IPA sekolah pasca sarjana UPI.

Samatowa, U. (2010). Pembelajaran IPA di Sekolah Dasar. Jakarta: PT Indeks.

Suprijono, A. (2014). Cooperative learning teori dan aplikasi PAIKEM. Yogyakarta: Pustaka Pelajar.

Tan, O.S. (2004). Enhancing thinking through problem-based learning approaches:international perspectives. Singapore: cengage learning.

Tawil, M \& Liliasari. (2014). Keterampilan-keterampilan sains dan implementasinya dalam pembelajaran IPA. Makasar: Badan Penerbit Universitas Makasar 